\title{
Evaluation of the Effectiveness and Efficiency of the Government Regulation Implementation Number 12 of 2019
}

\author{
Icuk Rangga Bawono ${ }^{1^{*}}$, Adhitia Pradana ${ }^{2}$ and Apriani Kartika Rahayu ${ }^{3}$ \\ 1,3 Faculty of Economics and Business of Jenderal Soedirman University \\ ${ }^{2}$ Advocate and Law Consultant \\ *Correspondence: cukycutes@yahoo.com
}

How to cite (in APA style):

Bawono, I. R., Pradana, A., \& Rahayu, A. R. (2021). Evaluation of the Effectiveness and Efficiency of the Government Regulation Implementation Number 12 of 2019. Jurnal Hukum Prasada, 8(1), 1-7. doi: https://10.22225/jhp.8.1.2881.1-7

\begin{abstract}
The law should govern the dynamics of the nation and state life in an ideal country. For instance, Indonesia is a constitutional state that subjects to legal supervision based on the 1945 Constitution for state administration. Public policies are used as guidelines and references for actions, including financial management. However, regulations as the basis for regional financial management need to be adjusted to suit the dynamics in legal condition development and the community needs. Government Regulation Number 12 of 2019 is an improvement to Government Regulation Number 58 of 2005 on Regional Financial Management used as a reference in formulating regional financial management rules. This study examines the evaluation of the readiness to implement Government Regulation Number 12 of 2019 as the basis for regional financial management. The method used in this study is a normative legal research method. The legal materials source from primary and secondary legal material. The method in presenting this research result is deductive method. This study shows that financial management is a government responsibility in exercising regional power. The urgency of drafting a Regional Regulation on financial management is motivated by changes in legal dynamics and community needs for its management. Furthermore, there is a need for evaluation of the regulation improvement for effectiveness. In conclusion, the effectiveness and efficiency of regional financial management should be evaluated after Government Regulation Number 12 of 2019 is applied. The regulations need to be disseminated for the wider community response to be identified for evaluation of improvements and adjustments to its needs.
\end{abstract}

Keywords: Government; Regional Financial; Regional Government; Rule Adjustment

\section{INTRODUCTION}

The law should govern the dynamics of the nation and state life in an ideal country (Asshiddiqie, 2007). All authority actions in a state of law are essential for a clear legal basis (Harahap, 2001). Indonesia is subject to legal supervision based on the 1945 Constitution in the administration of state power.

The community, government, and local governments jointly participate in national development, including the aspects of the nation and state life. In discharging its duties, the government has three main functions, including distribution, stabilization, and allocation roles. The central government focuses on these three functions to ensure there is financial balance in the regional governments. According to Article 18A paragraph (2) of the 1945 Constitution, regulating the implementation of public services, the use of finance, and the utilization of resources between the central and regional governments should be based on the law for justice. 
The demand for regional autonomy in Indonesia is non-negotiable because the development objectives should be implemented fairly and equitably. Regional autonomy is supported by Law Number 23 of 2014 on Regional Government. Each region has the power and responsibility to manage government affairs independently. Furthermore, regional autonomy aims to increase the efficiency and effectiveness of government administration and services to the community.

The financial balance between the central and regional governments indicates the implementation of regional autonomy. All revenues and expenditures under the region's responsibility should be listed in the Regional Revenue and Expenditure Budget $(A P B D)$ in the fiscal year. Regional Budget stipulation and amendment, as well as regional financial administration and accountability, should refer to a clear legal basis. Public policies are used as guidelines and references for actions, including financial management (Agustino, 2014). Accountable budget management stimulates the increase of regional economic capacity, and avoid bad budget execution practices to improve people's welfare (Purbadharmaja, 2010). Regionally, public policies in the form of Regional Regulations (Perda) and Regent Regulations (Perbup) are used as references, guidelines, and control of financial management in a certain region. Furthermore, accountability and transparency of local government are indicators of good governance. Increasing local sources of funding and creating mechanisms that ensure public officials are more accountable to enhance service delivery (Muzoora, 2018).

The implementation of decentralization should adhere to the good governance principles in regional government. This principle can optimize the community welfare acceleration and ensure all parties are involved in the management process (Waris, 2011). According to the State Administration Institute (LAN), good governance is the process of exercising the power to provide Public Good and Service in a country. LAN defines Good from the word good governance in two senses (Widodo, 2001). First, it is a value that is based on the wishes of the people and increases their ability as the basis for achieving goals. This is in line with the stewardship theory, which explains that stewardship puts the owner's interests in taking action (Donaldson \& Davis, 1991). In state life dynamics, the government as stewardship maximizes the utility function of society by providing the best public services to the community. Second, it is a functional aspect of government in carrying out tasks to achieve goals effectively and efficiently. The Value for Money (VFM) concept is used in the government performance assessment through the economy, efficiency, and effectiveness of the budgeting and finance utilization to fulfill community needs. In general, the provision of public services by the government should be based on community needs. The implementation of fiscal decentralization to improve community welfare can be achieved by increasing the regional economy capacity and implementing the good governance elements in budget management (Purbadharmaja, 2010). Good governance in financial management involves orderly management orderly, following the Law, efficiency, and being economical, effective, transparent, and responsible without neglecting the principles of justice, appropriateness, and benefits for the community.

Adjustment of regional financial policies to the legal situation and the community dynamic needs is required due to the increasing complexity of society's situation. The complexity may lead to new variables that can hinder the achievement of goals by both the government and society. Several issues emerged due to gaps in regional financial management regulations, including the distribution of social assistance funds and grants to the voters' bases of the political camp during the regional head elections in South Sumatra Province (Indrawan, 2015). The findings of the Financial Audit Agency (BPK) in 2017 show a gap in regional budget management which has decelerated the capital expenditures realization and increased bank deposits with local governments (Harjanto, 2017). For this reason, regional governments have failed to use their maximum regional financial capacities, leading to suboptimal financial management. Attaining financial capacity will lead to effective implementation decentralization and efficient service delivery (Muzoora, 2018). To eliminate the financial misuse in the government scope, especially in regional government, legal bases, such as Regional Regulations (Perda) or Regent Regulations (Perbup) need to be adjusted and be detailed and clear. They should adjust legal developments and the community scope 
in their regions. Furthermore, affirming sanctions is also needed to control violations of the regulations within the regional governments. There is no effective method to control the corruption gap in the regional government environment, except providing strict administrative and legal and legal sanctions (Labolo, 2017).

Public policy-making is a complex matter that requires a review of the processes and variables involved (Budi, 2014). Adjustments to regulations, such as Law Number 23 of 2014 affect the changes in local government regulations and regional financial management. Government Regulation (PP) Number 12 of 2019, which was recently issued and ratified, is an improvement to Government Regulation Number 58 of 2005 as the basis for financial management in a certain region. The improvement is meant to maintain the three pillars of financial management, which include transparency, accountability, and participation. A year after Government Regulation No. 12 of 2019 is applied, it is still not fully implemented due to several obstacles. This constraint should be evaluated in case of a future adjustment to the financial management regulations for more effectiveness and efficiency. Therefore, there is a need to evaluate the efficiency and effectiveness of the Government Regulation implementation Number 12 of 2019 in regions after issuance. This study examines the evaluation of the readiness to implement Government Regulation Number 12 of 2019 as the basis for regional financial management.

\section{METHODS}

This study uses a normative legal research method, which only examines library materials or secondary data (Soekanto \& Mamudji, 2015). According to Johny lbrahim, the normative legal method focuses on examining the implementation of positive law principles (Ibrahim, 2005). The steps used in collecting legal materials include taking inventory of laws and regulations related to research, library research, internet browsing, review of scientific articles and papers, and study of documents. Furthermore, this research also uses alternative data sources from influential authorities in society, prevailing traditions, common sense researchers, myths, and valid personal experiences. There is also a need for circumspection in filtering and processing alternative data. The legal materials obtained in the research are described by the author and connected to present it systematically to answer the problems formulated (Ibrahim, 2005). According to Peter Mahmud Marzuki, the deductive method is based on basic principles, where the object to be studied is then presented (Marzuki, 2005). The intended system is the overall data acquisition juxtaposed with other data and synchronized on the subject matter of the research for complete unity.

\section{RESULTS AND DISCUSSION}

According to Carl Fried, the definition of public policy is a series of actions proposed by a person or group in a certain environment to solve obstacles and uncertainties where the proposal is submitted. Making public policy is not a simple matter because the processes and variables involved need to be studied first (Budi, 2014). Public policy consists of several stages that aim to ease the public policies review, including agenda-setting, policy formulation, adoption, implementation, and evaluation.

Decentralization and good governance are essential parts of the democracy implementation process in a country. The good governance implementation ensures that the government mandate, authority, rights, and obligations given by the people are fulfilled. The form of good governance in financial management is carried out in an orderly manner and according to law, apart from being efficient, economical, transparent, effective, and responsible without neglecting the principles of justice, compliance, and benefits for the community. In general, good governance is implemented to create a professional government. Studies show that government managed by professional individuals enhances the performance of human resources in public organizations. They ensure governance is based on responsiveness, responsibility, and accountability.

According to LAN, good governance is a value that makes the people's will and the values of their capacity development as the basis for achieving goals. The achievements of a 
country are seen through sustainable development and social justice obtained by society. Stewardship theory explains that stewardship puts the owner's interests in taking actions (Donaldson \& Davis, 1991; Raharjo, 2007). The government as stewardship has the mandate to maximize the social utility function by making regulations to protect and manage assets and finances. Suppose it is related in the juridical context, the regional government acts as a policymaker, such as utilizing financial management as a guide in exercising authority. Regional governments as stewardship in formulating financial management policies should prioritize values that enhance the local community's ability to achieve goals. The formulation and enforcement of policies in the regions should be oriented to the community interests and aspirations.

Value For Money (VFM) in government can be used as a tool in assessing the organization's performance to achieve the expected goals. The VFM concept is constructed through 3E, which includes economy, effectiveness, and efficiency (Stewart \& Ranson, 1988). The economy referred to in VFM is the comparison of the inputs obtained for a certain quality option with the lowest selectable price and relates to efforts to avoid wasteful and ineffective expenditures. Furthermore, efficiency refers to achieving maximum output using the lowest input, while effectiveness is the achievement level on the planned target setting. The provision of community services should consider VFM to avoid and measure the level of inefficiency, waste, and leakage of government agency funds.

According to LAN, good governance is a value that makes people develop abilities as the basis for achieving goals. The objectives to be achieved should be in line with the mandate of paragraph IV of the 1945 Constitution Preamble. National development aims to realize social justice and welfare without neglecting the right to life and protection for every citizen. It is crucial for a country because it covers all aspects of the nation and state life that involves the community and central and regional governments. The government has the mandate to maximize the social utility function by prioritizing the community role as the main driver for national development.

The rapid population growth and increasingly complex problems make regional autonomy imperative. The basis for the authority delegation to the regions is contained in Law Number 23 of 2014 on Regional Government. Essentially, regional autonomy is expected to optimize empowerment and create public spaces, where people participate in the development process. The enactment of Law Number 23 of 2014 has had a significant impact on policies to regulate regional government, including regulations on financial management. The power to regulate regional financial sources, such as taxes and levies, as well as balancing funds occurs because autonomy power is granted to the regions. Furthermore, the governance delegation by regional governments should in line with the financial distribution. With a balance in financial sources, the government affairs delegated to the regions can be implemented. Attaining financial capacity leads to effective implementation of decentralization and efficient service delivery (Muzoora, 2018).

In discharging duties, the government has three main functions, including distribution, stabilization, and allocation. The distribution and stability functions are conducted more effectively by the central government, while the allocation is carried out by regional governments. This is because local governments have a better understanding of the needs, conditions, and situations of the local authority. These three functions are the basis for financial balance in the central and regional governments.

Regional financial management includes planning, implementation, administration, reporting, accountability, and supervision. There is a need to adhere to the good governance principles and accountability of regional financial management. Policies concerning regional financial management should be incorporated into statutory regulations regionally and immediately manifested as a government concern and responsibility to the community. The Regional Budget is crucial in policy instruments to increase the capability and effectiveness of regional governments. Furthermore, it is a significant determining tool for income and expenditure in decision making. Sources of regional revenue include Regional Original Income (PAD), balanced funds, and other legitimate, which should be based on the applicable regulations. Government Regulation Number 12 of 2019 is one of the main rules used as the 
basis for local governments in forming, determining, and managing the Regional Revenue and Expenditure Budget.

In 2019, the government issued and ratified Government Regulation 12 of 2019 as the basis for managing village finances. This complements Government Regulation Number 58 of 2005 as the basis for financial management. Improvements were made to maintain the three pillars of financial management, including transparency, accountability, and participation. There are two interesting points in Government Regulation No.12 of 2019. All regional revenues and expenditures should be recorded and managed in the Regional Revenue and Expenditure Budget. Second, the Regional Government has the authority to provide additional income for its regional civil servants. Increasing local sources of funding and creating mechanisms where public officials are more accountable enhances service delivery (Muzoora, 2018). However, a year after enactment, Government Regulation No.12 of 2019 still cannot be fully implemented due to obstacles. For instance, the issuance of this regulation is not accompanied by technical provisions or derivatives. Therefore, the regional government is given the authority to formulate these technical provisions, which is important in providing more specific legal certainty. This is because Government Regulation Number 12 of 2019 is a legitimate legal product.

Legal products without sufficient establishment can shackle and harm society with unnecessary paradoxes. The possibility of resistance to the law is very strong because it is formed based on the incompatibility of the society's spiritual structure (Syaukani \& Thohar, 2008). A legal system is a social phenomenon that always presents aspects of attitude and rule recognition behavior, as well as acceptable behavior (HLA, 2006). The regional regulation formation is important as a standard guide in implementing development. Furthermore, it is also needed in the policy formulation, apart from being a reference for regional development. The preparation and stipulation of regional regulations are prioritized to focus on improving the community welfare and always look at the needs and input from the community. Philosophically, regional financial management supports social welfare development and a manifestation of efforts to achieve the nation's ideals in the 5th Precept in Pancasila and the 1945 Constitution. The meaning contained in the philosophy of this nation shows that all Indonesians have the same social justice right.

In Pemalang Regency, derivative products from Government Regulation Number 12 of 2019 on financial management are contained in Regional Regulation Number 8 of 2020. Furthermore, the provision of additional income to regional civil servants is contained in Regent Regulation Number 6 of 2020. In Banjarnegara Regency, derivative products from Government Regulation Number 12 of 2019 are contained in Regent Regulation Number 15 of 2020. Similarly, Regent Regulation Number 10 of 2020 regulates additional income for regional civil servants. The scope of financial management in the Regional Regulations for these two regions includes several things, such as 1) the right to make loans and collect local levies and taxes, 2) the obligation to conduct regional government affairs and fulfill obligations to third parties, 3) regional revenues and expenditures, 4) management of regional resources and 5) assets belonging to other parties controlled by the regional government for the public interest and the implementation of government duties. However, the two regions can only form technicalities in 2020 after Government Regulation Number 12 of 2019 applies within one year.

Apart from the technicalities completed a year later, the two regions were constrained by the applications that were not maximally utilized in increasing Regional Original Revenue to implement financial management. Furthermore, the extensification of regional potential resources is still not maximally utilized. The ability of human resources in financial management is limited, hence not optimal in adjusting to the latest regulatory changes. Other obstacles in planning and implementing regional financial management include.

1. Intensification and extensification of taxes and levies have not been implemented optimally.

2. Data collection on tax objects/levies with low validity. 
3. The emergence of new regulations causing the regional potential exploration is not optimal.

4. Limited operational devices.

5. Limited budget for the assignment to increase Regional Original Revenue.

6. Regional Original Revenue Fluctuation.

7. Low awareness and understanding of taxpayers.

8. Financial coordination between the central and regency governments is less optimal;

9. Changes and delays in the technical guidelines for spending every year cause the Special Allocation Fund (DAK) revenue not to be optimal.

10. The rapid changes in the regional economic situation and the uncollectible income receivables often make the basis for incompatibility in setting tax rates and levies.

11. Management of several Regional Owned Enterprises is not optimal.

The Regional Regulations formulation should consider the provisions in Law Number 12 of 2011 and not deviate from the provisions of Law Number 9 of 2015 on Regional Government, Presidential Regulation Number 95 of 2018 on Electronic-Based Government Systems, Minister of Home Affairs Regulation Number 79 of 2018 on Regional Public Service Bodies, and Government Regulation Number 18 of 2016 on Regional Apparatus. Moreover, financial management policies should be in line with Law Number 17 of 2003, Law Number 1 of 2004, Law Number 15 of 2004, and Law Number 25 of 2004, as well as Government Regulation Number 12 of 2019. This rule can provide legal certainty and justice for stakeholders and the wider community. Furthermore, Law No.1 of 2004 provides a juridical basis regarding the state financial administration. Article 28 paragraph (3) describes the implementation of regional money management, which is further regulated through a Regional Regulation. The complexity of the rules for establishing Regional Regulations on financial management means that Regional Regulations cannot be completed and are passed in a short time. In case the formation of Regional Regulations cannot be implemented in a short time, there is technical confusion regarding financial management.

Regulatory reforms on financial management should conform to current policies. This means Regional or Regent Regulations on financial management based on time needs to be effective and efficient. The juridical reasons for the policy of Government Regulation Number 12 of 2019 were made to complement and improve regulations regarding regional financial management. Also, studies related to evaluating the effectiveness and efficiency of the readiness to implement Government Regulation Number 12 of 2019 are important due to the lack of specific technical implementation.

\section{CONCLUSION}

This study shows that regional financial management is the responsibility of the regional government achieved by exercising governance power. The urgency of drafting a regional regulation on financial management is motivated by changes in legal dynamics and community needs. Improvement of regional financial management regulations is needed to be effective and efficient. The issuance of Government Regulation Number 12 of 2019 on regional financial management philosophically fulfills the state objectives in the fourth Paragraph of the 1945 Constitution Preamble. Sociologically, regional financial management is the main problem hindering regional autonomy. To realize a good and effective governance concept, regional financial management is necessary. Juridically, this regulation should be supported by a Regional or a Regent Regulation that organized the technical implementation without contradicting the legal basis. Complementing and elaborating regulations concerning financial management should be carried out properly. Since the new Regional or Regent Regulation has not been effective, there have been regional financial management inefficiency because of the need to wait for the latest technical regulations. The effectiveness and efficiency of regional financial management should be evaluated after Government Regulation Number 12 of 2019 is applied. The regulations need to be disseminated for the wider community response to be identified for evaluation of improvements and adjustments to its needs. 


\section{REFERENCES}

Agustino, L. (2014). Politik Lokal Dan Otonomi Daerah. Bandung: Alfabeta.

Asshiddiqie, J. (2007). Pokok-Pokok Hukum Tata Negara Indonesia Pasca Reformasi. Jakarta: PT. Buana IImu Populer.

Budi, W. (2014). Kebijakan Publik: Teori, Proses, dan Studi Kasus (II). Yogyakarta: CAPS.

Donaldson, L., \& Davis, J. H. (1991). Stewardship Theory or Agency Theory: CEO Governance and Shareholder Returns. Australian Journal of Management, 16(1).

Harahap, Z. (2001). Hukum Acara Peradilan Tata Usaha Negara. Jakarta: PT Raja Grafindo Persada. Harjanto. (2017). Kemenkeu Ungkap "Kekacauan” Pengelolaan Anggaran Daerah.

HLA, H. (2006). Konsep Hukum (N. Mangunsong, Ed.). Nusamedia.

Ibrahim, J. (2005). Teori Dan Metodologi Penelitian Hukum Normatif. Malang: Bayumedia Publishing. Indrawan. (n.d.). AWASI! Ini 7 Celah Penyelewengan APBD Oleh Petahana Jelang Pilkada.

Labolo, M. (2017). Menutup Celah Korupsi Pemerintahan Daerah. Jurnal IImu Pemerintahan Widya Praja, 43(2).

Marzuki, P. M. (2005). Penelitian Hukum. Jakarta: Kencana Pranada Media Group.

Muzoora, A. R. (2018). The Impact of Decentralization on Good Governance In Uganda. Nkumba Business Journal, 17.

Purbadharmaja, I. B. P. (2010). Implikasi Desentralisasi Fiskal Dan Good Governance Di Bidang Tata Kelola Anggaran Terhadap Kapasitas Ekonomi Dan Kesejahteraan Masyarakat (Studi Pada Kabupaten/Kota Di Bali). Malang.

Raharjo, E. (2007). Teori Agensi Dan Teori Stewrship Dalam Perspektif Akuntansi. Fokus Ekonomi: Jurnal IImiah Ekonomi, 2(1).

Soekanto, S., \& Mamudji, S. (2015). Penelitian Hukum Normatif (Suatu Tinjauan Singkat). Jakarta: Rajawali Pers.

Stewart, J., \& Ranson, S. (1988). Management in the public domain. Public Money \& Management, $8(1-2)$.

Syaukani, I., \& Thohar, A. A. (2008). Dasar-Dasar Politik Hukum. Jakarta: PT Raja Grafindo Persada.

Waris, I. (2011). Pergeseran Paradigma Sentralisasi ke Desentralisasi Dalam Mewujudkan Good Governance. Jurnal Kebijakan Publik, 2(2).

Widodo, J. (2001). Good Governance: Telaah dari dimensi Akuntabilitas dan Kontrol Birokrasi Pada Era Desentralisasi dan Otonomi Daerah. Surabaya: Insan Cendekia. 